TP Periodica Polytechnica Social and Management Sciences

25(2), pp. 117-126, 2017

https://doi.org/10.3311/PPso.10052

Creative Commons Attribution (i)

\section{Motivation Preferences of Hungarian and Slovak Employees are Significantly Different}

\author{
Miloš Hitka ${ }^{1}$, Silvia Lorincová1 ${ }^{*}$, Lenka Ližbetinová $^{2}$ \\ Jarmila Schmidtová ${ }^{3}$
}

RESEARCH ARTICLE

\begin{abstract}
The aim of the paper is to compare the level of employee motivation in Hungary and Slovakia. Using sociological survey through questionnaires, a research was conducted in all regions of Hungary and Slovakia in 2016. Total of 30 motivation factors were divided into 5 groups of motivation factors. We analyzed motivation factors relating to mutual relationships, to career aspiration, to finance, to work conditions and to social needs. Significantly different preferences were observed in 4 of 5 groups of motivation factors preferred by Hungarian and Slovak respondents (motivation factors relating to mutual relationships, to career aspiration, to work conditions and to social needs). Surprisingly, motivation factors relating to mutual relationship were highly preferred by Hungarian respondents. Financial motivation factors were the most important for Slovak employees. Motivation factors relating to social needs were the least important for both groups of respondents. For Hungarian and Slovak employers, we recommend focusing on motivation factors relating to mutual relationships when creating motivation programmes. It will improve relations in the workplace. Simultaneously for Hungarian employers, our suggestion is to focus on motivation factors relating to career aspiration.
\end{abstract}

\section{Keywords}

employee motivation, motivation factors, Hungary, Slovakia

\footnotetext{
${ }^{1}$ Department of Business Economics,

Faculty of Wood Sciences and Technology,

Technical University in Zvolen

T. G. Masaryka 24, 96053 Zvolen, Slovak Republic

${ }^{2}$ Department of Tourism and Marketing, Faculty of Corporate Strategy, Institute of Technology and Business, České Budějovice, Czech Republic

${ }^{3}$ Department of Mathematics and Descriptive Geometry,

Faculty of Wood Sciences and Technology,

Technical University in Zvolen

T. G. Masaryka 24, 96053 Zvolen, Slovak Republic

*Corresponding author, e-mail: lorincova@tuzvo.sk
}

\section{Introduction}

The top priority of every enterprise is to get a place in the global market (Stacho et al., 2016). An enterprise is not just a set of numbers based on accounting, but it is the entity operating in a dynamically changing environment, which acts on it (Teplická et al., 2015). Due to the globalization, increasing competition, in such a turbulently changing business environment, only those companies that understand the current trends in global economy, may survive (Czajkowska and Stasiak-Betlejewska, 2015; Mura and Gašparíková, 2010; Potkány et al., 2016). Moreover, according to Kampf and Ližbetinová (2015), Kucharčíková (2014) and Sudzina et al. (2014), thanks to globalization, and changes in the economic development, the requirements on company competitiveness but also on the quality of human resources, are increasing. Based on Vaníčková (2015) success of the whole enterprise depends on human resources management. To be able to react to this situation, a big portion of organization's energy is put into the attention given to employees (Čambál and Cagáňová, 2010; ShaemiBarzoki et al., 2012). Ever increasing is thus the importance of personal dispositions, skills and knowledge of employees that affect their work performance (Myšková, 2015). Relying on their human force inside the organization, organizations can improve their activities as much as possible, and they can have an active participation in different markets (Foster, 2001). Clearly, to be able to fulfil the duties and responsibilities, the organization requires employees with some features such as innovation, good human relations, commitment to ethics, being interested in the job and service development, and constant effort (Blannie and Radhakrishna, 1991). Human capital is one of the enterprise inputs (Kucharčíková et al., 2016). Employees are more often perceived as an important tool for achieving business objectives and consequently corporate strategy (Sheehan et al., 2016). Human force is considered the most valuable asset of an organization and different factors affect its performance and efficiency (Lucas, 2004; ShaemiBarzoki et al., 2012). By Kachala (2014), human resources and their management are a source of competitive advantage for the business, rather than access to capital or technology used. Technology, processes and corporate structure can be copied but the value 
that competent and dedicated employees can bring to companies cannot be easily taken away (Ahmad et al., 2012).

The company will work effectively only when it manages to gather, connect together, star and constantly use human, material, financial and information resources (Hrehová and Cehlár, 2015). Nowadays, nobody doubts that success of every company on the global market, to a great extent, depends on how fast it can adjust to quick changes of the business environment (Antošová, 2010). Competitive environment in the domestic and international markets leads enterprises to a continuous improvement of the quality of offered products and services (Sheehan et al., 2016). The enterprise cannot achieve success if employees are dissatisfied with their jobs and are not sufficiently motivated (Lăzăroiu, 2015). Likewise, according to Baum and Kokkranikal (2005) continued success of any organisation is dependent on the employees' contribution and commitment.

The answer to the question "Why to motivate and stabilize workers?" is quite clear. Professional literature (Herzberg et al., 1959; Vroom, 1964; and other), as well as researches (Qayyum, 2012; Stanisic and Guerra, 2010) confirm that motivated enough and stable workers showed better results in the long term. They have a direct impact on customer satisfaction and this is reflected in the commercial and consequently in the financial success of an enterprise (Němečková, 2013). Similarly according to Jelačić et al. (2012) motivated employees come to work with enthusiasm and wish to fulfil their daily duties in a satisfying way. A good motivation programme can have a significant impact on company performance (Merková et al., 2015). Based on Rusu and Avasilcai (2014) achieving high performances in organizations requires motivated employees who are engaged in training activities, acquire knowledge, new abilities and skills, which they intend to share and communicate in order to improve the performance of their work activities and thus to contribute to the overall organizational performance. Increasing employee motivation can be achieved by the correct use of controlling concept of management, because highly motivated employees are the cause of high levels of labour productivity, it has effects on the performance and economic results of the organization in the competitive environment (Stopka et al., 2015; Šatanová and Potkány, 2004). Leete (2000) found that non-profit organizations rely on internally motivated employees unduly. Based on Buelens and Van den Broeck (2007) public sector employees are more motivated intrinsically. Public sector employees are more motivated by workload, personal growth, recognition, individual decision-making, interesting work and an opportunity to learn something new (Urbancová and Hudáková, 2015). According to Charan (2008) if the managers continue to treat the employees in the same way, their already low motivation for work will decrease even more. It can be said that practically all motivators are in the hands of the management (Kropivšek et al., 2011). The only question is if they know how to use them (Možina, 1998).
In the long term, motivation and employee performance are an essential tool for the success of any organization, according to Lăzăroiu (2015). Similarly Khan (2012) believes that only the organization that wants to enhance their employees' performance should focus on motivation in order to achieve higher performance levels. Jourbert (2007) asserts that motivation will drive performance towards the key performance areas. Following the opinion of Ibidunni et al. (2016) a culture of achievement supports tools of motivation and measurement of individual, group and organisational performance. The improvement of individual performance essentially depends on management of human resources and motivation of employees (Krajcsák and Gyökér, 2013).

Motivation can be defined in a number of ways. At a fairly straightforward level it could be described as: „What makes us do what we do." (Bagshawe, 2011). Motivation also means that somebody does something because he or she wants to do so, and what management has to do is to motivate and stimulate him or her in such a way as to encourage such an outlook (George and Jones, 1999; Herzberg, 2008). Motivation is the driver of cognition, action, and emotion (Kruglanski et al., 2016). However, a fuller definition might be: „Drives within a person that account for the degree, direction, and persistence of effort expendend at work." (Bagshawe, 2011). Based on Pritchard and Ashwood (2008) motivation is the process of turning energy into satisfied needs. The more fully our needs are met, the more need satisfaction we feel. The more our needs are not met, the more need dissatisfaction we feel. When we are very hungry, we feel uncomfortable. The hungrier we are, the more uncomfortable we feel. Need satisfaction feels good, we like it, and we try to achieve it. Conversely, need dissatisfaction feels bad, we do not like it, and we try to avoid it. As an example in the area of employee motivation people will not be motivated by rewards that do not satisfy their needs.

A motivated and qualified workforce is essential for any company that wants to increase productivity and customer satisfaction. In this context, motivation means the willingness of an individual to make efforts and take actions towards organizational goals. The challenge for any manager is to find the means to create and sustain employee motivation. On one hand, managers should focus on reducing job dissatisfaction (working conditions, salary, supervision, relationship with colleagues), while on the other hand, they should use motivation factors such as achievement, recognition, responsibility and the work itself (Dobre, 2013). Anitha (2014) identified six factors increasing employee's motivation such as working environment, management, training and professional development, wages, working place, team work and relationship to co-workers. Imhof, however, as early as in 2003, suggested and analysed a wider spectrum of motivation factors than Anitha (2014). Imhof's factors included: healthy working conditions, career opportunity, supportive boss, unambiguous and definite 
goals, competitive compensation, stable place of work, interesting job, high prestige, good performance evaluation, pleasant working atmosphere, peaceful private life, competent leadership, appreciation, participation in decision-making and fringe benefits. Nevertheless, there exist much more factors that influence employee motivation. Therefore, we have extended the overall scope of motivation factors to 30 (Table 1). The objective is to compare the level of employee motivation in Hungary and Slovakia and to recommend motivation factors motivating employees in motivation programmes.

\section{Methodology}

On a sample of 5,359 respondents, the importance level of 30 motivation factors was compared in Hungary and Slovakia. The method of random sampling was used to obtain the data from the whole territory of Hungary and Slovakia. Random selection met two characteristics. Firstly, for all statistical units belonging to the population, the probability of inclusion in the sample was not equal to zero. Secondly, the statistical units were selected independently of one another.

We used the methods of sociological research through anonymous questionnaires. The questionnaires were sent via email and evaluated by using Statistics 12.0 software (Dell, Oklahoma City, Oklahoma). Total of 30 motivation factors were analysed. Motivation factors were in alphabetical order not to affect respondent's decision. To identify the importance of motivation level, a five point rating scale was used. 5 was most important, 4 was very important, 3 was medium important, 2 was slightly important and 1 was unimportant (Hitka, 2009). The research was conducted in all regions of Hungary and Slovakia in 2016. To select respondents, the method of random sampling was used. Respondents working in various job positions were of different ages, completed education and different seniority by which we ensure the diversity of the sampling unit.

The research covered 915 respondents from Hungary and 4,444 respondents from Slovak Republic. In Hungary, the sampling unit consisted of $41.09 \%$ men and $58.91 \%$ women. In Slovakia, there was a comparable representation of men and women (49.66\% males and 50.38\% females). In terms of age structure, total of 535 respondents aged up to 30 years participated in Hungarian research (58.47\%). In Slovakia, the sampling unit consisted of $31.48 \%$ respondents aged 31 to 40 years. In the questionnaire research, there were $68.42 \%$ of Hungarian respondents and $39.00 \%$ of Slovak respondents with higher education. Concerning the seniority, Hungarian research sample consisted of $31.15 \%$ of those with seniority $7-9$ years. In Slovakia, nearly $33.08 \%$ of the respondents have been working in the company for more than 10 years. In terms of job category, managers represented the highest percentage of respondents in both countries (62.73\% in Hungary and $57.52 \%$ in Slovakia).

Descriptive statistic was used to characterize the sampling unit. The method of comparison was used to compare the values in sampling unit. The significance of differences of arithmetic means and standard deviations was tested at significance level of $\alpha=0.05$ in order to eliminate the statement that the differences found were not caused due to the representation fault. The statistical method through the average was used based on following equation (Schmidtová and Vacek, 2013):

$$
\bar{x}=\frac{\sum_{i=1}^{n} x_{i}}{n}
$$

where $\bar{x}$ is average, $x_{i}$ is individual values, $n$ is the total size of sampling unit. Given the scale and independence of the sample, Student two-sample t-test was used, when testing the null hypothesis of equal averages of motivation factors in terms of belonging to the country. Testing the null hypothesis was performed at the significance level $\alpha=0.05$.

Total of 30 motivation factors were investigated in terms of belonging to country (Table 2, Table 3) and gender (Table 4, Table 5). Subsequently, motivation factors were divided into five groups. We analysed motivation factors relating to mutual relationships (atmosphere in the workplace, good work team, communication in the workplace, supervisor's approach), to career aspiration (opportunity to apply one's own ability, career advancement, competences, prestige, individual decision-making, selfactualization, personal growth, recognition), to finance (base salary, fringe benefits, fair appraisal system), to work conditions (physical effort at work, occupational safety, job security, workload and type of work, information about performance result, working hours, work environment, job performance, mental effort, stress), and to social needs (social benefits, mission of the company, name of the company, region's development, relation to the environment, free time). Box and whisker plot (Fig. 1) and Table 8 presents the obtained results.

\section{Results and Discussion}

Anitha (2014) has identified six factors that help increase employee motivation. Nearly 20 motivation factors were analysed by Imhof, already in 2003. However, there are much more aspects that affect employee motivation. In our research, we analysed a total of 30 motivation factors.

Respondents evaluated each motivation factor. The average values of each motivation factor are shown in Table 1 in column mean. In the standard deviation column we see a deviation from the average value. Table 1 shows also 95\% confidence intervals for Hungarian and Slovak employee, which represents minimum and maximum value. Following the results, we can state that with a $95 \%$ confidence, when rating the atmosphere in the workplace, Hungarian employees would give this factor an average rating from 4.69 to 4.76 in a similar survey. Slovak employees would give this factor an average rating from 4.36 to 4.41 in a similar survey. Based on the results, Hungarian respondents rated the atmosphere in the workplace more 
Table 1 Descriptive statistics and $95 \%$ confidence intervals

\begin{tabular}{|c|c|c|c|c|c|c|c|c|}
\hline \multirow{2}{*}{ Motivation factors } & \multicolumn{4}{|c|}{$\mathrm{HU}$} & \multicolumn{4}{|c|}{ SK } \\
\hline & Mean & $\begin{array}{l}\text { Standard } \\
\text { deviation }\end{array}$ & $-95.00 \%$ & $95.00 \%$ & Mean & $\begin{array}{l}\text { Standard } \\
\text { deviation }\end{array}$ & $-95.00 \%$ & $95.00 \%$ \\
\hline Atmosphere in the workplace & 4.73 & 0.57 & 4.69 & 4.76 & 4.38 & 0.81 & 4.36 & 4.41 \\
\hline Base salary & 4.63 & 0.62 & 4.59 & 4.67 & 4.45 & 0.88 & 4.42 & 4.47 \\
\hline Communication in the workplace & 4.43 & 0.76 & 4.38 & 4.48 & 4.24 & 0.86 & 4.22 & 4.27 \\
\hline Competences & 4.61 & 0.61 & 4.57 & 4.65 & 3.86 & 0.94 & 3.84 & 3.89 \\
\hline Fair appraisal system & 4.03 & 0.98 & 3.97 & 4.10 & 4.37 & 0.85 & 4.34 & 4.39 \\
\hline Free time & 4.18 & 0.91 & 4.12 & 4.24 & 4.07 & 0.92 & 4.05 & 4.10 \\
\hline Information about performance result & 4.03 & 0.82 & 3.98 & 4.09 & 3.91 & 0.94 & 3.88 & 3.93 \\
\hline Job performance & 4.43 & 0.72 & 4.38 & 4.47 & 4.11 & 0.83 & 4.08 & 4.13 \\
\hline Job security & 4.43 & 0.75 & 4.38 & 4.48 & 4.37 & 0.86 & 4.35 & 4.40 \\
\hline Mental effort & 4.42 & 0.67 & 4.37 & 4.46 & 4.01 & 0.94 & 3.98 & 4.03 \\
\hline Mission of the company & 3.93 & 0.96 & 3.87 & 4.00 & 3.85 & 0.98 & 3.82 & 3.88 \\
\hline Name of the company & 3.77 & 1.09 & 3.69 & 3.84 & 3.85 & 1.06 & 3.82 & 3.88 \\
\hline Opportunity to apply one's own ability & 4.54 & 0.70 & 4.50 & 4.59 & 4.00 & 0.88 & 3.97 & 4.02 \\
\hline Relation to the environment & 4.07 & 0.99 & 4.00 & 4.13 & 3.90 & 1.01 & 3.87 & 3.93 \\
\hline Selfactualization & 4.24 & 0.75 & 4.19 & 4.29 & 3.94 & 0.91 & 3.91 & 3.97 \\
\hline Social benefits & 4.57 & 0.71 & 4.52 & 4.62 & 4.07 & 0.93 & 4.05 & 4.10 \\
\hline Stress & 4.54 & 0.67 & 4.50 & 4.58 & 4.06 & 0.93 & 4.03 & 4.09 \\
\hline Supervisor's approach & 4.63 & 0.62 & 4.59 & 4.67 & 4.38 & 0.84 & 4.36 & 4.41 \\
\hline Work environment & 4.34 & 0.68 & 4.30 & 4.39 & 4.15 & 0.86 & 4.13 & 4.18 \\
\hline Working hours & 4.27 & 0.83 & 4.21 & 4.32 & 4.17 & 0.88 & 4.14 & 4.20 \\
\hline Workload and type of work & 4.41 & 0.69 & 4.37 & 4.45 & 4.09 & 0.86 & 4.07 & 4.12 \\
\hline
\end{tabular}

positively than Slovak respondents. As Table 1 shows, total of 25 motivation factors acquired higher values of the selected averages when rated by Hungarian respondents.

In the following step, total of 30 motivation factors were tested using statistical methods. The aim was to test the assumption that there are significant differences in level of motivation, depend on belonging to a country. Results are presented in Table 2.

Table 2 shows the difference of mean between motivation factors in Hungary and Slovakia. Motivation factors with significant differences are highlighted in bold in the column p-level. We observed statistically significant difference in the majority of motivation factors ( $\mathrm{p}$-level is lower than $5 \%$, in Table 2 in column p-level). The difference is too large to be considered random. Insignificant differences occurred in five motivation factors (workload and type of work, competences, supervisor's approach, individual decision-making and fair appraisal system).

In the following step, the motivation factors were ordered by the level of importance, as they were rated by the respondents. Motivation factors were ordered according to the arithmetic mean. The order of all motivation factors preferred by Hungarian and Slovak respondents is illustrated in Table 3. Top 10 motivation factors considered most important by Hungarian and Slovak employees are highlighted in bold. Atmosphere in the workplace and base salary were considered the most important motivation factors by Hungarian respondents. Following motivation factors were considered important by Hungarian respondents (superior's approach, personal growth, competences, social benefits, career advancement, stress, opportunity to apply one's own ability, fringe benefits). Hungarian employees recognized fringe benefits to be important, however, they 
Table 2 Hypothesis testing

\begin{tabular}{|c|c|c|c|c|}
\hline Motivation factors & $\begin{array}{l}\text { HU } \\
\text { Mean }\end{array}$ & $\begin{array}{l}\text { SK } \\
\text { Mean }\end{array}$ & $\mathrm{t}$-test & p-level \\
\hline Atmosphere in the workplace & 4.73 & 4.38 & -15.48 & 0.000 \\
\hline Base salary & 4.63 & 4.44 & -7.75 & 0.000 \\
\hline Career advancement & 4.61 & 3.98 & -26.18 & 0.000 \\
\hline Communication in the workplace & 3.77 & 4.24 & 12.53 & 0.000 \\
\hline Competences & 3.83 & 3.86 & 0.95 & 0.343 \\
\hline Fair appraisal system & 4.42 & 4.37 & -1.87 & 0.062 \\
\hline Free time & 4.62 & 4.07 & -23.03 & 0.000 \\
\hline Fringe benefits & 4.51 & 4.31 & -7.95 & 0.000 \\
\hline Good work team & 2.76 & 4.39 & 38.61 & 0.000 \\
\hline Individual decision-making & 4.03 & 3.98 & -1.65 & 0.099 \\
\hline Information about performance result & 4.27 & 3.91 & -11.74 & 0.000 \\
\hline Job performance & 4.55 & 4.11 & -17.91 & 0.000 \\
\hline Job security & 4.43 & 4.37 & -2.14 & 0.033 \\
\hline Mental effort & 4.24 & 4.01 & -8.24 & 0.000 \\
\hline Mission of the company & 3.54 & 3.85 & 7.72 & 0.000 \\
\hline Name of the company & 4.54 & 3.85 & -24.70 & 0.000 \\
\hline Opportunity to apply one's own ability & 4.41 & 4.00 & -15.68 & 0.000 \\
\hline Personal growth & 4.18 & 4.03 & -4.46 & 0.000 \\
\hline Physical effort at work & 4.43 & 3.77 & -23.26 & 0.000 \\
\hline Prestige & 4.63 & 3.68 & -37.47 & 0.000 \\
\hline Recognition & 3.93 & 4.12 & 5.26 & 0.000 \\
\hline Region's development & 4.07 & 3.80 & -7.22 & 0.000 \\
\hline Relation to the environment & 4.38 & 3.90 & -16.28 & 0.000 \\
\hline Selfactualization & 4.57 & 3.94 & -23.07 & 0.000 \\
\hline Social benefits & 4.54 & 4.07 & -17.99 & 0.000 \\
\hline Stress & 3.97 & 4.06 & 2.74 & 0.006 \\
\hline Supervisor's approach & 4.37 & 4.38 & 0.52 & 0.604 \\
\hline Work environment & 4.43 & 4.15 & -10.17 & 0.000 \\
\hline Working hours & 4.34 & 4.17 & -6.69 & 0.000 \\
\hline Workload and type of work & 4.03 & 4.09 & 1.92 & 0.056 \\
\hline
\end{tabular}

Note: Significantly different motivation factors are in bold.

did not consider them as important as Slovak respondents. This motivation factor was the tenth most preferred by Hungarian employee while for Slovak respondents it was seventh important motivation factor. The research shows (Table 3) that base salary is the most important motivation factor for employees in Slovakia. Within the financial factors, fringe benefits were important for Slovak respondents. Non-financial factors as good work team, atmosphere in the workplace, supervisor's approach, job security, fair appraisal system, communication in the workplace, working hours and work environment were important for Slovak employees.

The top 10 motivation factors considered by employees as the most important, were subject to a more detailed analysis using the methods of inductive statistics (Table 4, Table 5)

Table 4 shows statistically significant differences of 10 most important motivation factors from the point of view of Hungarian
Table 3 Comparison of the order of all motivation factors for Hungarian and Slovak employees (ordered according to the arithmetic mean)

\begin{tabular}{|c|c|c|c|}
\hline \multicolumn{2}{|l|}{ HU } & \multicolumn{2}{|l|}{ SK } \\
\hline Motivation factors & Mean & Motivation factors & Mean \\
\hline $\begin{array}{l}\text { Atmosphere in the } \\
\text { workplace }\end{array}$ & 4.73 & Base salary & 4.44 \\
\hline Base salary & 4.63 & Good work team & 4.39 \\
\hline Supervisor's approach & 4.63 & $\begin{array}{l}\text { Atmosphere in the } \\
\text { workplace }\end{array}$ & 4.38 \\
\hline Personal growth & 4.62 & Supervisor's approach & 4.38 \\
\hline Competences & 4.61 & Job security & 4.37 \\
\hline Social benefits & 4.57 & Fair appraisal system & 4.37 \\
\hline Career advancement & 4.55 & Fringe benefits & 4.31 \\
\hline Stress & 4.54 & $\begin{array}{l}\text { Communication in the } \\
\text { workplace }\end{array}$ & 4.24 \\
\hline $\begin{array}{l}\text { Opportunity to apply one's } \\
\text { own ability }\end{array}$ & 4.54 & Working hours & 4.17 \\
\hline Fringe benefits & 4.51 & Work environment & 4.15 \\
\hline $\begin{array}{l}\text { Communication in the } \\
\text { workplace }\end{array}$ & 4.43 & Recognition & 4.12 \\
\hline Job security & 4.43 & Job performance & 4.11 \\
\hline Job performance & 4.43 & Workload and type of work & 4.09 \\
\hline Mental effort & 4.42 & Free time & 4.07 \\
\hline Workload and type of work & 4.41 & Social benefits & 4.07 \\
\hline Recognition & 4.38 & Stress & 4.06 \\
\hline Individual decision-making & 4.37 & Personal growth & 4.03 \\
\hline Work environment & 4.34 & Mental effort & 4.01 \\
\hline Working hours & 4.27 & $\begin{array}{l}\text { Opportunity to apply one's } \\
\text { own ability }\end{array}$ & 4.00 \\
\hline Selfactualization & 4.24 & Career advancement & 3.98 \\
\hline Free time & 4.18 & Individual decision-making & 3.98 \\
\hline Relation to the environment & 4.07 & Selfactualization & 3.94 \\
\hline Fair appraisal system & 4.03 & $\begin{array}{l}\text { Information about } \\
\text { performance result }\end{array}$ & 3.91 \\
\hline $\begin{array}{l}\text { Information about } \\
\text { performance result }\end{array}$ & 4.03 & Relation to the environment & 3.90 \\
\hline Good work team & 3.97 & Competences & 3.86 \\
\hline Mission of the company & 3.93 & Mission of the company & 3.85 \\
\hline Prestige & 3.83 & Name of the company & 3.85 \\
\hline Name of the company & 3.77 & Region's development & 3.80 \\
\hline Region's development & 3.54 & Physical effort at work & 3.77 \\
\hline Physical effort at work & 2.76 & Prestige & 3.68 \\
\hline
\end{tabular}

men and women. Based on the results presented in Table 4, statistically significant differences can be seen in all 10 motivation factors from the point of view of Hungarian men and women.

Table 5 shows the averages of the motivation factors of Slovak men and women and the difference between them that determines the extent of identifying with the motivation factor by Slovak men and women. Following the values the difference in the level of motivation factors of Slovak men and women can be seen. 
Table 4 Statistically significant differences of motivation factors from the point of view of Hungarian respondents analysed according to the gender

\begin{tabular}{|c|c|c|c|c|c|c|}
\hline \multirow{2}{*}{ Motivation factors } & \multicolumn{2}{|c|}{ Mean } & \multirow{2}{*}{ t-test } & \multirow{2}{*}{ p-level } & \multicolumn{2}{|c|}{ Standard deviation } \\
\hline & Men & Women & & & Men & Women \\
\hline $\begin{array}{l}\text { Atmosphere in the } \\
\text { workplace }\end{array}$ & 4.34 & 4.81 & -6.02 & 0.000 & 0.96 & 0.39 \\
\hline Base salary & 4.31 & 4.70 & -6.06 & 0.000 & 0.77 & 0.56 \\
\hline $\begin{array}{l}\text { Career } \\
\text { advancement }\end{array}$ & 4.16 & 4.64 & -7.21 & 0.000 & 0.80 & 0.58 \\
\hline Competences & 4.34 & 4.67 & -5.03 & 0.000 & 0.78 & 0.55 \\
\hline Fringe benefits & 4.28 & 4.56 & -3.80 & 0.000 & 0.88 & 0.57 \\
\hline $\begin{array}{l}\text { Opportunity to } \\
\text { apply one's own } \\
\text { ability }\end{array}$ & 4.19 & 4.62 & -5.63 & 0.000 & 0.92 & 0.62 \\
\hline Personal growth & 4.34 & 4.68 & -6.06 & 0.000 & 0.64 & 0.55 \\
\hline Social benefits & 4.31 & 4.62 & -4.35 & 0.000 & 0.85 & 0.67 \\
\hline Stress & 4.19 & 4.62 & -6.60 & 0.000 & 0.77 & 0.62 \\
\hline $\begin{array}{l}\text { Supervisor's } \\
\text { approach }\end{array}$ & 4.34 & 4.69 & -4.73 & 0.000 & 0.89 & 0.53 \\
\hline
\end{tabular}

Note: Significantly different motivation factors are in bold.

Table 5 Statistically significant differences of motivation factors from the point of view of Slovak respondents analysed according to the gender

\begin{tabular}{|c|c|c|c|c|c|c|}
\hline \multirow{2}{*}{ Motivation factors } & \multicolumn{2}{|c|}{ Mean } & \multirow{2}{*}{ t-test } & \multirow{2}{*}{ p-level } & \multicolumn{2}{|c|}{ Standard deviation } \\
\hline & Men & Women & & & Men & Women \\
\hline $\begin{array}{l}\text { Atmosphere in the } \\
\text { workplace }\end{array}$ & 4.31 & 4.45 & -5.98 & 0.000 & 0.82 & 0.79 \\
\hline Base salary & 4.42 & 4.46 & -1.53 & 0.126 & 0.88 & 0.88 \\
\hline $\begin{array}{l}\text { Communication in } \\
\text { the workplace }\end{array}$ & 4.16 & 4.32 & -6.37 & 0.000 & 0.88 & 0.82 \\
\hline Fair appraisal system & 4.35 & 4.38 & -1.24 & 0.215 & 0.82 & 0.87 \\
\hline Fringe benefits & 4.28 & 4.34 & -2.25 & 0.024 & 0.89 & 0.85 \\
\hline Good work team & 4.36 & 4.43 & -3.24 & 0.001 & 0.85 & 0.76 \\
\hline Job security & 4.35 & 4.39 & -1.64 & 0.100 & 0.86 & 0.85 \\
\hline $\begin{array}{l}\text { Supervisor's } \\
\text { approach }\end{array}$ & 4.32 & 4.44 & -4.62 & 0.000 & 0.85 & 0.81 \\
\hline Work environment & 4.09 & 4.21 & -4.49 & 0.000 & 0.89 & 0.83 \\
\hline Working hours & 4.14 & 4.19 & -1.89 & 0.058 & 0.89 & 0.86 \\
\hline
\end{tabular}

Note: Significantly different motivation factors are in bold.

Atmosphere in the workplace, communication in the workplace, fringe benefits, good work team, supervisor's approach, and working environment were motivation factors where significant differences were found from the point of view of Slovak men and women (Table 5). Mutual consensus was found in base salary, fair appraisal system, job security, and working hours.

In the following step, our aim was to compare the groups of motivation factors in terms of their similarities. Therefore, motivation factors were divided into five groups (motivation factors relating to mutual relationship, to career aspiration, to finance, to work conditions and to social needs). In the column frequency, the cumulation of motivation factors related to all five groups is provided. Subsequently, average value is calculated as we focused on the position of analysed groups depending on country. The results are shown in Table 6 and Table 7.

Subsequently, using Student two-sample t-test it was verified that the averages of the importance of 5 groups of motivation factors are statistically significantly different (Table 8, Fig. 1).

Table 6 Groups of motivation factors rated by Hungarian respondents

\begin{tabular}{|c|c|c|c|c|c|c|}
\hline \multirow{2}{*}{\multicolumn{2}{|c|}{$\begin{array}{l}\text { Motivation } \\
\text { factors relating to: }\end{array}$}} & \multirow{2}{*}{ Frequency } & \multirow{2}{*}{ Mean } & \multirow{2}{*}{$\begin{array}{l}\text { Standard } \\
\text { deviation }\end{array}$} & \multicolumn{2}{|c|}{ Confidence interval } \\
\hline & & & & & $-95.00 \%$ & $95.00 \%$ \\
\hline 1. & $\begin{array}{l}\text { mutual } \\
\text { relationship }\end{array}$ & 3,600 & 4.44 & 0.79 & 4.41 & 4.46 \\
\hline 2. & $\begin{array}{l}\text { career } \\
\text { aspiration }\end{array}$ & 6,405 & 4.40 & 0.77 & 4.38 & 4.41 \\
\hline 3. & finance & 2,745 & 4.39 & 0.80 & 4.36 & 4.42 \\
\hline 4. & $\begin{array}{l}\text { work } \\
\text { conditions }\end{array}$ & 7,320 & 4.15 & 0.98 & 4.13 & 4.17 \\
\hline 5. & social needs & 5,490 & 4.01 & 1.02 & 3.98 & 4.04 \\
\hline
\end{tabular}

Table 7 Groups of motivation factors rated by Slovak respondents

\begin{tabular}{|c|c|c|c|c|c|c|}
\hline \multirow{2}{*}{\multicolumn{2}{|c|}{$\begin{array}{l}\text { Motivation } \\
\text { factors relating to: }\end{array}$}} & \multirow{2}{*}{ Frequency } & \multirow{2}{*}{ Mean } & \multirow{2}{*}{$\begin{array}{l}\text { Standard } \\
\text { deviation }\end{array}$} & \multicolumn{2}{|c|}{ Confidence interval } \\
\hline & & & & & $-95.00 \%$ & $95.00 \%$ \\
\hline 1. & $\begin{array}{l}\text { mutual } \\
\text { relationship }\end{array}$ & 17,776 & 4.35 & 0.83 & 4.34 & 4.36 \\
\hline 2. & $\begin{array}{l}\text { career } \\
\text { aspiration }\end{array}$ & 31,108 & 3.94 & 0.93 & 3.93 & 3.95 \\
\hline 3. & finance & 13,332 & 4.37 & 0.87 & 4.36 & 4.39 \\
\hline 4. & $\begin{array}{l}\text { work } \\
\text { conditions }\end{array}$ & 35,552 & 4.07 & 0.92 & 4.06 & 4.08 \\
\hline 5. & social needs & 26,664 & 3.92 & 0.10 & 3.91 & 3.94 \\
\hline
\end{tabular}

Table 8 Statistically significant differences in prefference of Hungarian and Slovak respondents ordered according to the group of motivation factors

\begin{tabular}{|c|c|c|c|c|c|c|c|}
\hline \multirow{2}{*}{\multicolumn{2}{|c|}{$\begin{array}{l}\text { Motivation factors } \\
\text { relating to: }\end{array}$}} & \multicolumn{2}{|c|}{ Mean } & \multirow{2}{*}{ t-test } & \multirow{2}{*}{ p-level } & \multicolumn{2}{|c|}{ Standard deviation } \\
\hline & & $\mathrm{HU}$ & SK & & & $\mathrm{HU}$ & SK \\
\hline 1. & $\begin{array}{l}\text { mutual } \\
\text { relationship }\end{array}$ & 4.44 & 4.35 & -6.10 & 0.000 & 0.79 & 0.83 \\
\hline 2. & $\begin{array}{l}\text { career } \\
\text { aspiration }\end{array}$ & 4.40 & 3.94 & -41.04 & 0.000 & 0.77 & 0.93 \\
\hline 3. & finance & 4.39 & 4.37 & -1.03 & 0.303 & 0.81 & 0.87 \\
\hline 4. & $\begin{array}{l}\text { work } \\
\text { conditions }\end{array}$ & 4.15 & 4.07 & -6.85 & 0.000 & 0.98 & 0.92 \\
\hline 5. & social needs & 4.01 & 3.92 & -5.66 & 0.000 & 1.02 & 0.10 \\
\hline
\end{tabular}

Note: Significantly different groups of motivation factors are in bold.

Differences in preferences can be observed in 4 of 5 groups of motivation factors (motivation factors relating to mutual relationship, to career aspiration, to work conditions, to social needs) (Table 8, Fig. 1). The group of motivation factors relating to finance was the only one where no statistically significant differences in preferences can be seen from the point of 
view of employees working in Hungary and Slovakia, even despite the fact that group of motivation factors relating to finance was most important for Slovak employees (Category 3 in right side of Fig. 1). The group of motivation factors relating to finance was the third most important group for Hungarian respondents (Category 3 in left side of Fig. 1).

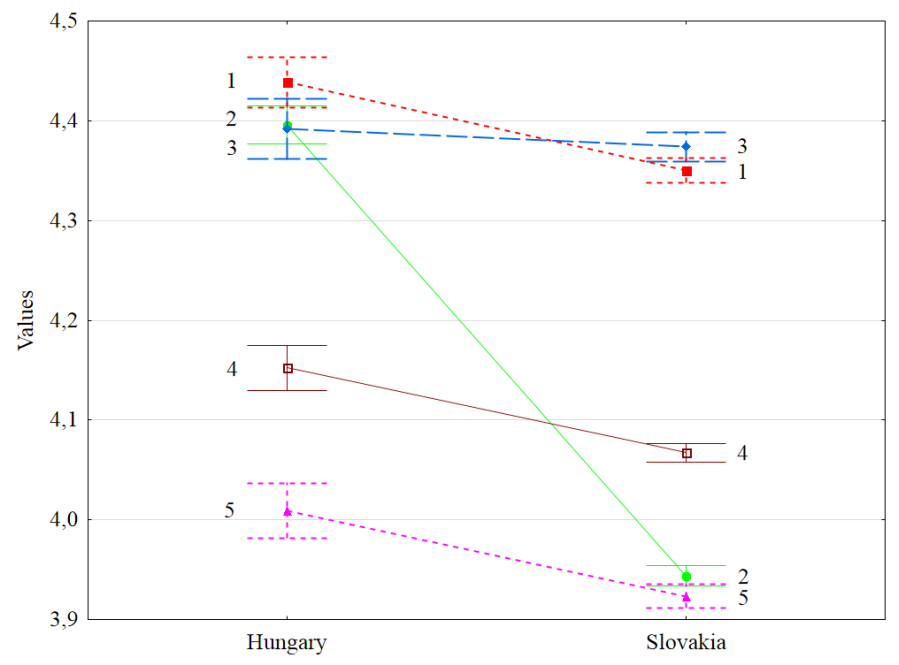

Fig. 1 Box and whisker plot: 95\% confidence intervals for average values of importance of groups of motivation factors ordered according to the country. Categories: 1 , relating to mutual relationship; 2, relating to career aspiration; 3 , relating to finance; 4 , relating to work conditions; 5 , relating to social needs

According to the Statistical Office of the Slovak Republic (2016) and Eurostat (2016b), in Slovakia, there is a higher average salary than in Hungary. Actually, according to Eurostat (2016a) fewer products can be bought by Slovak employees compared to Hungarian employees. It may be the reason why base salary was more preferred by Slovak respondents. Similarity can be seen in the Maslow's hierarchy of needs (1943) because physiological needs are placed at the bottom of the hierarchy. Motivation factors relating to the finance are influenced by macroeconomic indicators of the state. Therefore, their application to motivation programmes is directly dependent on economic results of an enterprise.

The group of motivation factors relating to mutual relationship was the most important for Hungarian respondents (Category 1 in left side of Fig. 1). On the other hand, this group was the second most important for Slovak respondents. According to Kollárik (2002) good atmosphere and relationships between co-workers have a positive effect on employees. Consequently, the employee performance is higher, compared to the situation when communication in the workplace does not work. Similarly, if the supervisor's approach is not suitable, it will be reflected in the employee performance.

Based on the gathered data, motivation factors relating to the work conditions were rated as the fourth most important for Hungarian respondents, and the third most important for Slovak employees (Category 4 in Fig. 1).
Further results show that motivation factors relating to the career aspiration were places at the top positions in Hungary but these factors were less important for Slovak respondents (Category 2 in Fig. 1). In Slovakia, the fourth group of motivation factor was the group of motivation factors relating to career aspiration. Similar results are presented by Sarnovičs (2010). According to author, career growth and prestige are important factors for employees. Employees trust to their employers and they build a career. They feel motivated to retain their jobs. According to Jehanzeb et al. (2012) job satisfaction, especially prestige and authority are increased by career factors. The results can be affected by sampling unit. The research provided by Jehanzeb et al. (2012) was focused on young respondents with higher education. Career advancement is typical for employees with higher education. Sampling unit in our research consisted of many Slovak respondents with higher education, but career advancement is not important for them. Our results can be influenced by the age of respondents, too. Therefore, we recommend providing the research repeatedly. The more attention must be paid to motivation factors relating to career aspiration.

Based on the results of our research, the last group of motivation factors with the lowest level of importance was represented by group of motivation factors relating to social needs (Category 5 in Fig. 1). We assume that in both countries, social support and company policy are at a high level. Employees are satisfied in this area. As a result, they do not considered motivation factors relating to social needs as very important.

We suggest that the more attention must be paid to motivation factors relating to mutual relationship when creating motivation programmes in Hungary and in Slovakia. It will improve mutual relationships in the workplace. Our further recommendation for Hungarian employers is to focus on motivation factors relating to career aspiration, too.

When creating motivation programs in Hungary, we recommend focusing on the groups of motivation factors related to mutual relationship, career aspiration and finance. Specifically, we recommend focusing on the following motivation factors. In the group of motivation factors related to mutual relationship: atmosphere in the workplace, supervisor's approach, communication in the workplace. In the group of career motivation factors: personal growth, competences, career advancement, opportunity to apply one's own ability. In the group of motivation factors related to finance, we recommend focusing on base salary and fringe benefits. These motivation factors in the motivation programs will be effective in the majority of Hungarian enterprises.

In Slovakia, it is necessary to focus on groups of motivation factors related to finance and mutual relationship. For Slovak employers we recommend focusing on the following motivation factors. In the area of finance, it is appropriate to use base salary, fringe benefits and fair appraisal system. Following motivation factors related to mutual relationship should be 
used: good work team, atmosphere in the workplace, supervisor's approach, communication in the workplace.

The differences in proposed motivation programmes can be observed. It confirms the differences in the needs of employees of the countries surveyed.

\section{Conclusion}

In today's highly competitive marketplace, business cannot be regarded as a closed and an isolated system (Marková and Lesníková, 2015; Rajic et al., 2013). Nowadays, business environment has become highly competitive because of globalisation. Companies have to improve their own decision making process, which must correspond with the world's changes. The long-time business strategy cannot use traditional techniques to corporate improvement. It is necessary to come up with new ideas to be different from competitors in order to survive in the global market (Milichovský, 2015). The similar opinion is shared by Stone and Deadrick (2015). The authors say that movements in economy, domestic diversity and technology create new organisation demands propelling the human resources in some completely new directions. Human resource researchers maintain that changes are being triggered by globalization, increased generational diversity, and expanded interest in innovation and sustainability (Boudreau et al., 2014; Roehling et al., 2005). Today organization can easily change their material, needs, goods and services to other organization, or to other countries. But the only resource which is not easily exchangeable is human resources (Zameer et al., 2014).

As the results of the research show, motivation factors relating to the mutual relationship were considered as the most important by Hungarian employees. On the other hand, motivation factors relating to finance were the most important for Slovak employees and at the same time the third most important for Hungarian employees. Based on the results, we can conclude that different motivation factors and different groups of motivation factors were preferred by employees working in Hungary and Slovakia. The preferences were not similar at all. Different ways of motivation must be used by employers to motivate Hungarian and Slovak employees. Moreover, motivation factors preferred by employees need to be re-evaluated periodically as some of them are subject to change. Motivation is influenced by employee needs because people have many needs that are continuously competing one with another. Each person has a different mixture and strength of needs, as some people are driven by achievement while others are focusing on security. If managers are able to understand, predict and control employee behaviour, they should also know what the employees expect from their jobs. Therefore, it is essential for a manager to understand what really motives employees, without making just an assumption (Dobre, 2013).

In the next period, after the extending of the sampling unit, motivation can be analyzed more closely in terms of age and education differences.

\section{Acknowledgement}

This research was supported by VEGA 1/0024/17 and VEGA 1/0537/16.

\section{References}

Ahmad, M. B., Wasay, E., Malik, S. U. (2012). Impact of employee motivation on customer satisfaction. Interdisciplinary Journal of Conemporary Research in Business. 4(6), pp. 531-539.

Anitha, J. (2014). Determinants of employee engagement and the impact on employee performance. International Journal of Productivity and Performance Management. 63(3), pp. 308-323. https://doi.org/10.1108/IJPPM-01-2013-0008

Antošová, M. (2010). Manažment l’udských zdrojov a organizačný rozvoj ako východisko znalostného manažmentu. (Human resources management and organizational development as a basis for the knowledge management.) Acta Montanistica Slovaca. 15(1), pp. 90-95. (in Slovak)

Bagshawe, A. (2011). How to Improve Motivation. Anthony Bagshawe \& Ventus Publishing ApS.

Baum, T., Kokkranikal, J. (2005). Human resource management in tourism. Thomson, London.

Blannie, B. E., Radhakrishna, B. R. (1991). Job satisfaction of agricultural education faculty instructors: A constant phenomena. Journal of Agricultural Education. 6(2), pp. 41-52.

Boudreau, J., Gibson, C., Ziskin, I. (2014). What is the future of HR? HR leaders generally feel their ideal role is one of broad leadership, but it is often far less than that. Workforce.

Buelens, M., Van Den Broeck, H. (2007). An Analysis of Differences in Work Motivation between Public and Private Sector Organizations. Public Administration Review. 67(1), pp. 65-74. https://doi.org/10.1111/j.1540-6210.2006.00697.x

Charan, R. (2008). Leadership in the Era of Economic Uncertainty: Managing in a Downturn. McGraw-Hill.

Czajkowska, A., Stasiak-Betlejewska, R. (2015). Quality management tools applying in the strategy of logistics services quality improvement. Serbian Journal of Management. 10(2), pp. 225-234.

Čambál, M., Cagáňová, D. (2010). Corporate Culture Influence on Effective Initialization and Application of Knowledge Management in Enterprises In: Proceedings of the 11th European Conference on Knowledge Management, Universidade Lusiada de Vila Nova de Famalicao, Famalicao, Portugal, Academic Publishing International, pp. 176-181.

Dobre, O. I. (2013). Employee motivation and organizational performance. Review of Applied Socio- Economic Research. 5(1), pp. 53-60

Eurostat, (2016a). Price level index for 4 groups of goods and services.

Eurostat, (2016b). Wages and labour costs.

Foster, S. (2001). Managing quality and integrative approach. Prentice-Hall, New Jersey, 2001.

George, J. M., Jones, G. R. (1999). Understanding and Managing Organizational Behaviour. Addison-Wesley, Reading, MA.

Herzberg, F., Mausner, B., Snyderman, B. B. (1959). The motivation to work John Wiley \& Sons, New York.

Herzberg, F. (2008). One More Time: How Do You Motivate Employees?. Harvard Business Press, Boston.

Hitka, M. (2009). Model analýzy motivácie zamestnancov výrobných podnikov. (Model of analysis of employees motivation in manufacturing enterprises.) Technical University in Zvolen, Zvolen. (in Slovak)

Hrehová, D., Cehlár, M. (2015). Quality human resources are most precious for the company. In: International Multidisciplinary Scientific GeoConference and EXPO, SGEM 2015, Albena, Bulgaria. 
Ibidunni, S., Osibanjo, O., Adeniji, A., Salau, O. P., Falola, H. (2016). Talent Retention and Organizational Performance. Periodica Polytechnica Social and Management Sciences. 24(1), pp. 1-13.

https://doi.org/10.3311/PPso.7958

Imhof, E. (2003). Comparing occupational and gender differences on motivational structure. Periodica Polytechnica Social and Management Sciences. 11(2), pp. 237-247.

Jehanzeb, K., Rasheed, M., Rasheed, A., Aamir A. (2012). Impact of Rewards and Motivation on Job Satisfaction in Banking Sector of Saudi Arabia. International Journal of Business and Social Science. 3(21), pp. 272-278.

Jelačić, D., Moro, M., Drábek, J., Sujová, A. (2012). Motivation factors in wood processing plants. Wood Research. 57(2), pp. 317-330.

Joubert, D. (2007). Talent Management: Deliberate practice for success. Knowres Publishing, Randburg, Republic of South Africa.

Kachala, B. (2014). Review of the Role of Motivation on Employee Performance. Mediterrane an Journal of Social Science. 5(17), pp. 39-48. https://doi.org/10.5901/mjss.2014.v5n17p39

Kampf, R., Ližbetinová, L. (2015). The Identification and Development of Talents in the Environment of Logistics Companies. Naše more. 62(3), pp. 139-142. https://doi.org/10.17818/NM/2015/SI9

Khan, M. I. (2012). The impact of training and motivation on performance of employees. Business Review. 7(2), pp. 84-95.

Kollárik, T. (2002). Sociálna psychológia práce. (Social Psychology of Work.) Centre for Continuing Education of the Comenius University in Bratislava, Bratislava. (in Slovak)

Krajcsák, Z., Gyökér, I. (2013). How to increase workplace commitment? Periodica Polytechnica Social and Management Sciences. 21(1), pp. 39-44. https://doi.org/10.3311/PPso.2155

Kropivšek, J., Jelačić, D., Grošelj, P. (2011). Motivating Employees of Slovenian and Croatian Wood-industry Companies in Times of Economic Downturn. Drvna Industrija. 62(2), pp. 97-103. https://doi.org/10.5552/drind.2011.1040

Kruglanski, A. W., Chernikova, M., Jasko, K. (2016). Aspects of motivation: reflections on Roy Baumeister's essay. Motivation and Emotion. 46(1), pp. 11-15. https://doi.org/10.1007/s11031-015-9534-6

Kucharčíková, A. (2014). Investment in the Human Capital as the Source of Economic Growth. Periodica Polytechnica Social and Management Sciences. 22(1), pp. 29-35. https://doi.org/10.3311/PPso.7426

Kucharčíková, A., Konušíková, L., Tokarčíková, E. (2016). Approaches to the quantification of the human capital efficiency in enterprises. Komunikacie. 18(1a), pp. 49-54.

Lăzăroiu, G. (2015). Employee motivation and job performace. Linguistic and Philosophical Investigations. 14, pp. 97-102.

Leete, L. (2000). Wage Equity and Employee Motivation in Nonprofit and ForProfit Organizations. Journal of Economic Behavior \& Organization. 43(4), pp. 423-446. https://doi.org/10.1016/S0167-2681(00)00129-3

Lucas, R., Marinova, M., Kucerova, J., Vetráková, M. (2004). HRM practice in emerging economies: A long way to go in the Slovak hotel industry? International Journal of Human Resource Management. 15(7), pp. 1262 1279. https://doi.org/10.1080/0958519042000238446

Marková, V., Lesníková, P. (2015). Utilization of Corporate Sustainability Concept at Selected Enterprises in Slovakia. Procedia Economics and Finance. 34, pp. 630-637. https://doi.org/10.1016/S2212-5671(15)01678-0

Maslow, A. H. (1943). A Theory of Human Motivation. Psychological Review. 50(4), pp. 370-396.

Merková, M., Drábek, J., Jelačić, D. (2015). Evaluation of investment management and business performance in wood processing industry in Slovakia. Drvna Industrija. 66(3), pp. 241-249.

https://doi.org/10.5552/drind.2015.1439
Milichovský, F. (2015). Financial Key Performance Indicators in Engineering Companies. Periodica Polytechnica Social and Management Sciences. 23(1), pp. 60-67. https://doi.org/10.3311/PPso.7810

Možina, S. (1998). Zadovoljstvo zaposlenih in motivacija za poslovno odličnost. (Employee satisfaction and motivation for business excellence.) Industrijska demokracija. (Industrial democracy.) pp. 5-8. (in Croatian)

Mura, L., Gašparíková, V. (2010). Penetration of small and medium sized food companies on foreign markets. Acta Universitatis Agriculturae et Silviculturae Mendelianae Brunensis. 58(3), pp. 157-164. https://doi.org/10.11118/actaun201058030157

Myšková, R. (2015). Assessing the degree of balance between staff dispositions and their job positions using fuzzy logic. Scientific Papers of the University of Pardubice, Series D, Faculty of Economics and Administration. 22(34), pp. 113-124.

Němečková, I. (2013). The role of salary in employee motivation and retention in the financial sector of the Czech Republic in relation to Herzberg's two factor theory of work motivation. Politická ekonomie. 3, pp. 373-392.

Potkány, M., Stasiak-Betlejewska, R., Kováč, R., Gejdoš, M. (2016). Outsourcing in contidions of SMEs - The potential for cost savings. Polish Journal of Management Studies. 13(1), pp. 145-156. https://doi.org/10.17512/pjms.2016.13.1.14

Pritchard, R. D., Ashwood, E. L. (2008). Managing Motivation. A manager's guide to diagnosing and improving motivation. Routledge Taylor \& Francis Group, New York.

Qayyum, A. (2012). An Empirical Analysis of Employee Motivation and the Role of Demographics. Global Business \& Management Research. 4(1), pp. 1-14.

Rajic, T., Dado, J., Taborecka-Petrovicova, J. (2013). Linking retail service quality, satisfaction and perceived value to cutomer behavioral intentions: Evidence from Serbia. E\& M: Ekonomie a Management. 16(2), pp. 99-112.

Roehling, M. V., Boswell, W. R., Caligiuri, P., Feldman, D., Graham, M. E., Guthrie, J. P. (2005). The future of HR management: Research needs and directions. Human Resource Management. 44(2), pp. 207-216. https://doi.org/10.1002/hrm.20066

Rusu, G., Avasilcai, S. (2014). Factors Influencing Employees' Motivation for Knowledge Communication. Advanced Materials Research. 837, pp. 657-662. https://doi.org/10.4028/www.scientific.net/AMR.837.657

Sarnovičs, A. (2010). Human Resource Development in public administration: A case of Latvia. Human Resources Management \& Ergonomics. 4(1), pp. 1-12.

ShaemiBarzoki, A, Attafar, A., RezaJannati, A. (2012). An Analysis of Factors Affecting the Employees Motivation based on Herzberg's Hygiene Factors Theory. (The study: Golpayegan City Saipa Corporation Industrial Complex's Staff). Australian Journal of Basic and Applied Sciences. 6(8), pp. 115-123.

Sheehan, C., De Cieri, H., Cooper, B., Shea, T. (2016). Strategic implications of HR role management in a dynamic environment. Personnel Review. 45(2), pp. 353-373. https://doi.org/10.1108/PR-04-2014-0071

Schmidtová, J., Vacek., V. (2013). Applied Statistics. Technical University in Zvolen, Zvolen.

Stacho, Z., Potkány, M., Stachová, K., Marcineková, K. (2016). The organizational culture as a support of innovation processes' management: a case study. International Journal of Quality Research. 10(4), pp. 769-784

Stanisic, N., Guerra, M. (2010). Serbian Employees Work Motivation Research Done on Specific Sample. Singidunum Scientific. 7(1), pp. 180-188.

Stone, D. L., Deadrick, D. L. (2015). Challenges and opportunities affecting the future of human resource management. Human Resource Management Review. 25(2), pp. 139-145. https://doi.org/10.1016/j.hrmr.2015.01.003 
Stopka, O., Šimková, I., Konečný, V. (2015). The quality of service in the public transport and shipping industry. Nase More. 62(3), pp. 126-130. https://doi.org/10.17818/NM/2015/SI7

Sudzina, F., Razmerita, L., Kirchner, K. (2014). Educational On-Line Gaming Propensity: An Exploratory Study. New Educational Review. 35(1), pp. 17-28.

Šatanová, A., Potkány, M. (2004). Controlling - Modern tool of company control. Ekonomicky casopis. 52(2), pp. 148-165.

Štatistický úrad Slovenskej republiky (Statistical Office of the Slovak Republic) (2016). Náklady práce. (Labor costs.) Bratislava. (in Slovak)

Teplická, K., Daubner, M., Augustínová, E. (2015). Analysis of causal relationships between selected factors in process of performance management in industrial companies in Slovakia. Ekonomicky casopis. 63(5), pp. 504-523.
Urbancová, H., Hudáková, M. (2015). Employee development in small and medium enterprises in the light of demographic evolution. Acta Universitatis Agriculturae et Silviculturae Mendelianae Brunensis. 63, pp. 1043-1050. https://doi.org/10.11118/actaun201563031043

Vaníčková, R. (2015). Corporate personnel policy and personnel strategy. Klaipèda University, Klaipèda.

Vroom, V. H. (1964). Work and Motivation. John Wiley \& Sons, Inc., USA.

Zameer, H., Ali, S., Nisar, W., Amir, M. (2014). The Impact of the Motivation on the Employee's Performance in Beverage Industry of Pakistan. International Journal of Academic Research in Accounting, Finance and Management Sciences. 4(1), pp. 293-298.

https://doi.org/10.6007/IJARAFMS/v4-i1/630 